\title{
Analisis Kelengkapan Utilitas Halte Trans Metro Pekanbaru Jalan Pasir Putih dan Jalan Pandau Permai
}

\author{
Wilsen Harefa' ${ }^{1}$, V.T. Haris ${ }^{2}$, Winayati ${ }^{3}$. \\ Program Studi Teknik Sipil, Fakultas Teknik, Universitas Lancang Kuning \\ Jl. Yos Sudarso km. 8 Rumbai, Pekanbaru, Telp. (0761) 52324 \\ Email: wilsenh23@gmail.com,virgotrisepharis@gmail.com,winayatimt@gmail.com.
}

ABSTRAK

Trans Metro Pekanbaru sebagai transportasi umum massal yang menggunakan bus sebagai transportasi pilihan bagi masyarakat Pekanbaru, pembangunan halte sebagai tempat pemberhentian untuk menurunkan dan menaikkan penumpang yang di lengkapi dengan bangunan. Dalam Pembangunan halte di Jalan Pandau Permai dan Jalan Pasir Putih, calon penumpang Trans Metro Pekanbaru mengeluhkan akan kondisi bangunan halte. Saat pemberhentian bus di halte sering mengakibatkan kemacetan, bus berhenti pada ruas jalan disebabkan halte tidak memiliki ruang khusus untuk berhenti. Pemilihan lokasi halte maupun fasiltas-fasilitas halte yang di butuhkan sangat perlu dalam pembangunan halte, dalam pembangunan kebutuhan halte telah di atur oleh direktur jenderal perhubungan darat sesuai dengan Surat Keputusan Nomor: 271/HK.105/DRJD/96 "Pedoman Teknis Perekayasaan Tempat Perhentian Kendaraan Penumpang Umum". Oleh sebab itu di lakukanya analisi kelengkapan utilitas halte di jalan pandau permai dengan menggunakan metode penelitian kualitatif sebagai pedoman dalam penilitian ini. Dari 11 halte yang telah di analisis nilai persentasi tertinggi kelengkapan yang sudah ada sebesar 36,36\% dan nilai terendah 9,09\% dari hasil persentase penilaian kelengkapan berada pada kondisi kurang lengkap. Masih banyak kekurangan fasilitas-fasilitas yang harus di lengkapi dalam pembangunan halte, agar dapat merasakan kenyamanan dalam menggunakan halte dan dapat menjadi sarana transportasi umum untuk mengurangi pertumbuhan penggunaan kendaraan pribadi.

Kata Kunci : Fasilitas, Jenis Pemberhentian, Utilitas Halte.

\section{ABSTRACT}

Trans Metro Pekanbaru which a bus is as the publics' choices of the mass public transportation in Pekanbaru. The bus shelter construction which as a stopping place to take and leave the passengers should complete with the building. The prospective passengers of Trans Metro Pekanbaru complain about the condition of the bus shelter at Pandau Permai street and Pasir Putih street. The stopping bus often causes the congestion because it does not have a stopping space. It usually stops on the road. The selection of the bus shelter location or the bus shelter facilities is necessary for the bus shelter construction. The bus shelter construction arranged by The Director General of Land Transportation according to The Decision Letter Number: 271/HK.105/DRJD/96 "The Guidelines of The Technical Engineering of The Public Vehicles Stopover". Therefore, the researcher had done the complete analysis of the bus shelter utilities at Pandau Permai street. This research uses the qualitative research method as the guidelines of this research. The completeness percentage of the assessment result showed us that from 11 bus shelter had 36,36\% of the higher completion percentage and 9,09\% of the lower completion percentage. In conclusion, there is many other facilities lack of the bus shelter construction so that the people will fell comfort to use the bus shelter and it will be a public transportation to reduce the private vehicle growth.

Keyword: The Facilities, The Kind of Bus shelter, The Bus shelter Utilities. 


\section{Pendahuluan}

Pemerintah kota Pekanbaru secara resmi meluncurkan Trans Metro Pekanbaru sebagai transportasi umum massal yang menggunakan bus sebagai transportasi pilihan bagi masyarakat Pekanbaru. Dinas Perhubungan Darat Kota Pekanbaru telah membangun halte di sepanjang lintasan untuk melayani kebutuhan pemberhentian bus. Operasional kegiatan bus dimulai dari pukul 06.00 WIB sampai pukul 20.00 WIB dan melayani 8 Koridor yang menjangkau seluruh kota Pekanbaru.

Dalam peraturan pembangunan kebutuhan halte telah di atur oleh direktur jenderal perhubungan darat sesuai dengan Surat Keputusan Nomor: 271/HK.105/DRJD/96 "Pedoman Teknis Perekayasaan Tempat Perhentian Kendaraan Penumpang Umum". Pada pembangunan halte bus di kota pekanbaru banyak permasalahan yang muncul baik dalam pemilihan lokasi pembangunan halte maupun fasiltas-fasilitas penunjang halte yang belum memadai. Salah satunya adalah halte yang berada di sepanjang jalan Pandau Permai. Halte tersebut dibangun di atas trotoar, sehingga mengganggu aktifitas pejalan kaki. Permasalahan yang turut memperburuk kondisi lalu lintas adalah penyempitan jalan pada ruas jalan yang padat arus lalu lintasnya. Saat pemberhentian bus di halte sering mengakibatkan kemacetan, bus berhenti pada ruas jalan di karnakan halte tidak memiliki ruang khusus untuk berhenti.

Calon penumpang Trans Metro Pekanbaru juga mengeluhkan akan kondisi bangunan halte yang berada di sepanjang jalan Pasir Putih, salah satu keluhan yang di alami calon penumpang Trans Metro Pekanbaru adalah ruangan halte yang tidak terawat, tempat duduk yang kurang baik dan suasana panas di ruangan halte. Hal serupa juga terjadi pada halte yang lainya, halte yang sudah tidak memiliki dinding, dan atap yang tidak berfungsi semestinya lagi. Fasilitas-fasilitas utama lainnya juga belum ada, seperti belum adanya jadwal keberangkatan, papan informasi, tidak adanya zebra cross, dan belum adanya lampu penerangan halte.

\section{Metode Penelitian}

Metode Penelitian yang digunakan dalam menganalisis kelengkapan utilitas Halte ini adalah Penelitian Kualitatif. Penelitian ini berada di rute koridor 1 dan halte yang ditinjau di sepenjang jalan Pasir Putih Dan jalan Pandai Permai. Dalam penilitain ini pada jalan Pasir Putih dan Panau Permai ada 11 hallte yang melayani Trans Metro Pekanbaru, dan halte tersebut memiliki jenis halte dan tipe pemberhentian halte yang berbeda-beda.

Penelitian mengenai Evaluasi kelayakan halte Trans Metro Pekanbaru dilakukan mengikuti diagram alir berikut ini.

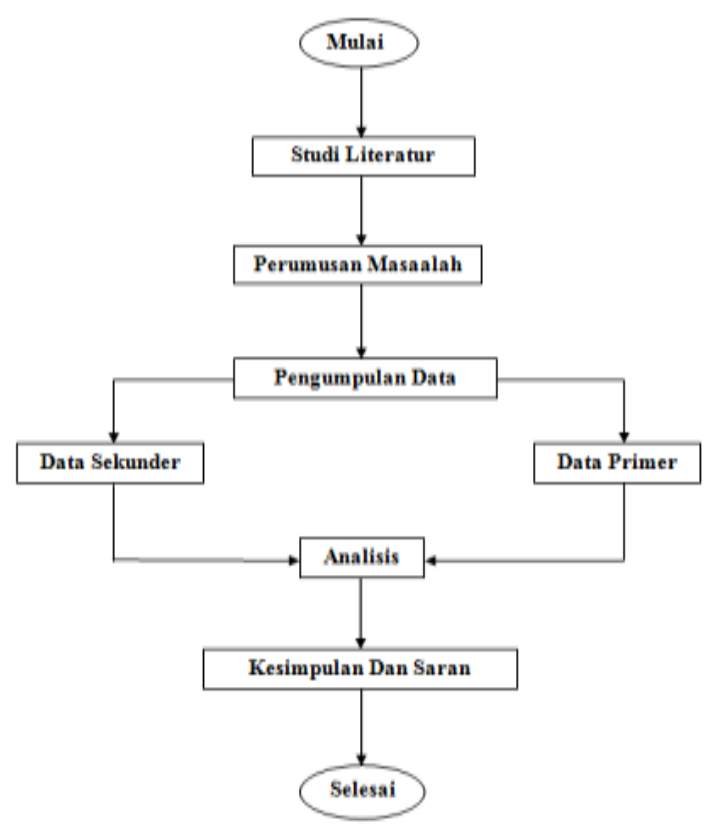

Gambar 1. Diagram Alir Penelitian

\section{HASIL DAN PEMBAHASAN}

\section{Penentuan jarak antara halte}

Dikarnakan halte yang digunakan dalam melayani angkutan Trans Metro Pekanbaru sudah tidak memiliki identitas, maka penulis memberikan angka untuk mempermudah dalam menentukan Jarak. Halte yang berada di jalan pasir putih dan pandau permai dapat kita lihat pada tabel, sebagai berikut.

Tabel 1. Jarak halte

\begin{tabular}{|c|c|c|}
\hline No & Nama Halte & Jarak Halte (meter) \\
\hline 1 & 01 & 430 \\
\hline 2 & 02 & 773 \\
\hline 3 & 03 & 520 \\
\hline 4 & 04 & 440 \\
\hline 5 & 05 & 620 \\
\hline 6 & 06 & 715 \\
\hline 7 & 07 & 218 \\
\hline 8 & 08 & 582 \\
\hline 9 & 09 & \multirow{2}{*}{5} \\
\hline 10 & 10 & \\
\hline 11 & 11 & \\
\hline
\end{tabular}

(Sumber : Data hasil survei, 2017)

Berdasarkan Keputusan Jirektorat Jendral Perhubungan Darat No 271/HK.105/DRJD/96 dalam penentuan jarak halte yang di anjurkan dalam kota 300500 meter dan untuk pinggiran kota 500-1000 meter.

Data geometrik jalan 
Dalam penilitian ini Trans Metro Pekanbaru melewati jalan Pasir Putih dan Pandau Permai data geometrik sebagai berikut :

1. Jalan pasir putih

Jalan pasir putih adalah jalan Arteri data geometrik dapat di lihat pada tabel sebagai berikut:

Tabel 2. Geometrik jalan Pasir Putih

\begin{tabular}{|c|c|c|}
\hline No & Geometrik Jalan & $\begin{array}{c}\text { Dua-lajur-dua-arah } \\
\text { terhagi }(2 / 2 \mathrm{D})\end{array}$ \\
\hline 1 & Lebar Jalur & 7 meter \\
\hline 2 & Lebar bahu & 1,5 meter \\
\hline 3 & Median & Tidak ada \\
\hline 4 & Trotoar & Tidak ada \\
\hline 5 & Jalur Hijau & Tidak ada \\
\hline
\end{tabular}

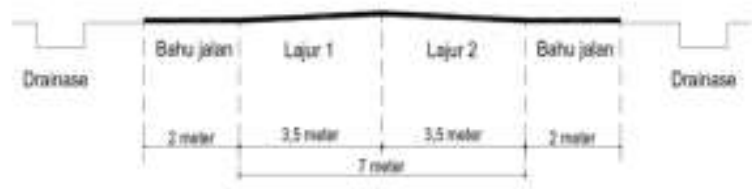

Gambar 2. Potongan melintang jalan Pasir Putih (Sumber : Data hasil survei, 2017)

2. Jalan pandau permai

Jalan pandau permai adalah jalan komplek perumahan, data geometrik dapat di lihat pada tabel 3 sebagai berikut;

Tabel 3. Geometrik jalan Pandau Permai

\begin{tabular}{|c|c|c|}
\hline No & Geometrik Jalan & $\begin{array}{c}\text { Empat-lajur-dua-arah } \\
\text { terbagi }(4 / 2 \mathrm{D})\end{array}$ \\
\hline I & Lebar Jahur & 13 meter \\
\hline 2 & Lebar bahu & Tidak ada \\
\hline 3 & Median & 1.5 meter \\
\hline 4 & Trotoar & 2 meter \\
\hline 5 & Jalur Hijau & Tidak ada \\
\hline
\end{tabular}

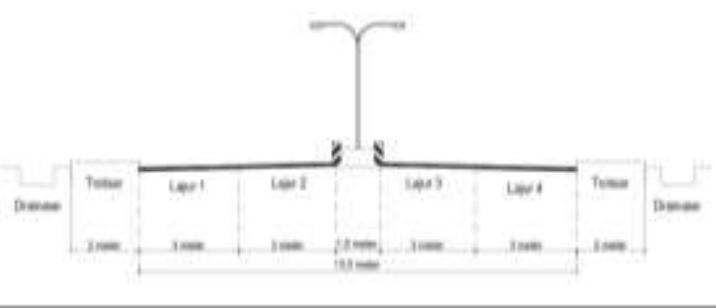

Gambar 3. Potongan melintang jalan Pandau Permai (Sumber : Data hasil survei, 2017)

\section{Penentuan tipe pemberhentian bus pada halte}

Tipe perhentian angkutan umum dibedakan berdasarkan posisi dari perhentian bus terhadap lalu lintas lainnya, tipe halte tersebut dapat di lihat pada tabel tipe halte sebagai berikut.

Tabel 4. tipe halte

\begin{tabular}{|c|c|c|}
\hline No & Nama Halte & \multirow{2}{*}{ Tipe Halte } \\
\hline 1 & 01 & \multirow{2}{*}{ lay-bys } \\
\hline 2 & 02 & \multirow{2}{*}{ curb-side } \\
\hline 3 & 04 & \\
\hline 4 & 05 & \\
\hline
\end{tabular}

\begin{tabular}{|c|c|l|}
\hline 5 & 07 & \multirow{2}{*}{ curb-side } \\
\hline 6 & 08 & \\
\hline 7 & 03 & curb-side \\
\hline 8 & 06 & curb-side \\
\hline 9 & 9 & curb-side \\
\hline 10 & 10 & curb-side \\
\hline 11 & 11 & curb-side \\
\hline
\end{tabular}

(Sumber : Data hasil survei, 2017)

\section{Jenis bangunan halte}

Jenis halte juga dapat di kelompokan menjadi beberapa jenis berdasarkan pemakaian, ketersediaan lahan, dan kondisi lingkungan. Jenis halte berdasarkan perhentian tersebut dapat di lihat pada tabel Jenis bangunan halte sebagai berikut.

Tabel 5. Jenis halte

\begin{tabular}{|c|c|c|c|}
\hline \multirow{2}{*}{ No } & \multirow{2}{*}{ Nama Halte } & \multicolumn{2}{|c|}{ Jenis Halte } \\
& & Ganda & Tunggal \\
\hline 1 & 01 & \multirow{2}{*}{ Ganda } & \\
\hline 2 & 02 & \multirow{2}{*}{ Ganda } & \\
\hline 3 & 04 & & \\
\hline 4 & 05 & \multirow{2}{*}{ Ganda } & \\
\hline 5 & 07 & & Tunggal \\
\hline 6 & 08 & & Tunggal \\
\hline 7 & 03 & & Tunggal \\
\hline 8 & 06 & & Tunggal \\
\hline 9 & 9 & & Tunggal \\
\hline 10 & 10 & & \\
\hline 11 & 11 & & \\
\hline
\end{tabular}

(Sumber : Data hasil survei, 2017)

\section{Jenis Kendaraan Operasional}

Bus Trans Metro Pekanbaru yang melewati koridor 1 menggunakan 12 unit armada kendaraan dengan jenis kendaraan bus lantai tunggal. Kendaraan bus Transmetro Pekanbaru menggunakan bahan bakar solar, berkapasitas 49 penumpang duduk dan 30 penumpang berdiri serta beberapa tempat untuk penumpang penyandang cacat yang menggunakan kursi roda dan dilengkapi AC (air conditioner). Dengan penggunaan bus besar lantai tunggal tersebut dapat melayani kebutuhan calon penumpang Trans Metro Pekanbaru yang berada pada koridor 1 .

\section{Kondisi Halte.}

Pembangunan halte berdasarkan peraturan dan kebutuhan yang harus terpenuhi dapat dilihat pada tabel berikut :

a) Kondisi fasilitas tambahan halte.

Fasilitas tambahan halte dapat di simpulkan dalam bebarapa fasilitas pada table fasilitas halte penunjang, sebagai berikut;

\section{Halte 01 dan halte 02 jenis halte ganda}

Halte ini berada di depan SD Negri 17 halte ini masuk pada kelompok halte yang di lengkapi dengan 
teluk bus, jenis halte ganda dan dilengkapi dengan teluk bus, Berikut ini hasil survai yang di lakukan pada halte.

Kondisi Fasilitas utama Halte 01

Tabel 8. Kondisi fasilitas utama halte 01

\begin{tabular}{|c|c|c|c|}
\hline No & Jenis Fasilitas & Kondisi & Keterangan \\
\hline 1 & Bangunan halte & Ada & $\begin{array}{l}\text { 1. Atap halte rusak danbocor } \\
\text { 2. Jendela kaca yang sudah pecah } \\
\text { 3. Plafon halte yang sudahtidak } \\
\text { ada }\end{array}$ \\
\hline 2 & Identitas halte & Belum ada & Belum terpasang pada halte \\
\hline 3 & Rambupetumjuk & Ada & $\begin{array}{l}\text { 1. Rambularangan parkir pada } \\
\text { halte ada. } \\
\text { 2. Rambularangan berhentipada } \\
\text { daerahperhentian TMP a da }\end{array}$ \\
\hline 4 & $\begin{array}{l}\text { Papan informasi } \\
\text { trayek }\end{array}$ & Belum ada & Belum terpasang pa da halte \\
\hline 5 & $\begin{array}{c}\text { Lampu } \\
\text { penerangan }\end{array}$ & Belum ada & Belum terpasang pa da halte \\
\hline 6 & Tempat duduk & Ada & $\begin{array}{l}\text { 1. Tempat duduk terbuat dari } \\
\text { beton, ukuran sandaran dan } \\
\text { lebar tempat duduk belum } \\
\text { memenuhi nilai kenyamanan } \\
\text { dalam halte. }\end{array}$ \\
\hline 7 & $\begin{array}{c}\text { Fasilitas } \\
\text { pengatur suhu } \\
\text { ruangan atau } \\
\text { ventilasi udara. }\end{array}$ & Ada & 1. Fentilasiudara masi terpasang \\
\hline 8 & $\begin{array}{c}\text { Fasilitas } \\
\text { Penyebrangan }\end{array}$ & Belum ada & $\begin{array}{l}\text { Fasilitas Penyebrangan Zebra } \\
\text { Croos Belum ada. }\end{array}$ \\
\hline
\end{tabular}

(Sumber : Data hasil survei, 2017)

Kondisi Fasilitas Penunjang halte 01

Tabel 9. Kondisi fasilitas penunjang halte 01

\begin{tabular}{|l|l|l|c|}
\hline No & $\begin{array}{l}\text { Fasilitas } \\
\text { tambahan }\end{array}$ & Kondisi & Keterangan \\
\hline 1 & Telephon umum & Belum ada & Belum terpasangpada halte \\
\hline 2 & Tempat sampah & Belum ada & Belum ada pada halte \\
\hline 3 & Pagarpengaman & Belum ada & Belum terpasang pada halte \\
\hline
\end{tabular}

Tabel kondisi fasilitas utama halte 02

Tabel 10. Kondisi fasilitas utama halte 02

\begin{tabular}{|c|c|c|c|}
\hline No & Jenis Fasilitas & Kondisi & Keterangan \\
\hline 1 & Bangunan halte & Ada & $\begin{array}{l}\text { 1. Kondisi ataphalte rusak dan } \\
\text { bocor } \\
\text { 2. Jendela kaca halte sebagian } \\
\text { pecah } \\
\text { 3. Plafon halte rusak }\end{array}$ \\
\hline 2 & Identitas halte & Belum ada & Belum terpasang pada halte \\
\hline 3 & Rambupetumjuk & Ada & $\begin{array}{l}\text { 1. Rambularangan parkir pada } \\
\text { halte ada. } \\
\text { 2. Rambularangan berhenti pada } \\
\text { daerahperhentian TMP a da }\end{array}$ \\
\hline 4 & $\begin{array}{c}\text { Papan informasi } \\
\text { trayek }\end{array}$ & Belum ada & Belum terpasangpada halte \\
\hline 5 & $\begin{array}{c}\text { Lampu } \\
\text { penerangan }\end{array}$ & Belum ada & Belum terpasangpada halte \\
\hline 6 & Tempat duduk & Ada & 1. Tempat duduk terbuat dari beton \\
\hline 7 & $\begin{array}{c}\text { Fasilitas } \\
\text { pengatur suhu } \\
\text { ruangan atau } \\
\text { ventilasi udara. }\end{array}$ & Ada & 1. Fentilasi udara masi terpasang \\
\hline 8 & $\begin{array}{c}\text { Fasilitas } \\
\text { Penyebrangan } \\
\end{array}$ & Belum ada & $\begin{array}{l}\text { Fasilitas Penyebrangan Zebra } \\
\text { Croos Belum ada }\end{array}$ \\
\hline
\end{tabular}

Kondisi Fasilitas penunjang halte 02

Tabel 11. Kondisi fasilitas penunjang halte 02

\begin{tabular}{|l|c|c|c|}
\hline No & Jenis Fasilitas & Kondisi & Keterangan \\
\hline 1 & Telephon umm & Belum ada & Belum terpasang pada halte \\
\hline 2 & Tempat sampah & Belum ada & Belum adapada halte \\
\hline 3 & Pagarpengaman & Belum ada & Belum terpasang pada halte \\
\hline
\end{tabular}

(Sumber : Data hasil survei, 2017)

\section{Halte 03}

Halte ini berada di depan pasar Jefri Nur, halte ini masuk pada kelompok tempat henti tunggal, berikut ini hasil survai yang di lakukan pada halte.

Tabel 12. Kondisi fasilitas utama halte 03

\begin{tabular}{|c|c|c|c|}
\hline No & Jenis Fasilitas & Kondisi & Keterangan \\
\hline 1 & Bangunan halte & Ada & $\begin{array}{l}\text { 1. Bangunanhalte ini tidak } \\
\text { mempunyai dinding. } \\
\text { 2. Memiliki kanopi yang mery orok } \\
\text { ke depan. }\end{array}$ \\
\hline 2 & Identitas halte & Belum ada & Belum terpasang pada halte \\
\hline No & Jenis Fasilitas & Kondisi & Keterangan \\
\hline 3 & Rambupetunjuk & Ada & $\begin{array}{l}\text { Tidak terdapat Rambulalu lintas } \\
\text { yangmemberi tahuletak halte, } \\
\text { danlaranganparkir pada area } \\
\text { halte. }\end{array}$ \\
\hline 4 & $\begin{array}{l}\text { Papaninformasi } \\
\text { trayek }\end{array}$ & Belum ada & Belum terpasang pada halte \\
\hline 5 & $\begin{array}{l}\text { Lampu } \\
\text { penerangan }\end{array}$ & Belum ada & Belum terpasang pa da halte \\
\hline 6 & Tempat duduk & Ada & $\begin{array}{l}\text { 1. Tempat duduk terbuat daripipa } \\
\text { besi. }\end{array}$ \\
\hline 7 & $\begin{array}{l}\text { Fasilitas } \\
\text { pengatur suhu } \\
\text { ruangan atau } \\
\text { ventilasi udara. }\end{array}$ & Belum ada & $\begin{array}{l}\text { Tidak memiliki fentilasi } \\
\text { bangunanhalte ini terbuka } \\
\text { dengan menggunakan kanopi. }\end{array}$ \\
\hline 8 & $\begin{array}{l}\text { Fasilitas } \\
\text { Penyebrangan }\end{array}$ & Belum ada & $\begin{array}{l}\text { Fasilitas Penyebrangan Zebra } \\
\text { Croos Belum ada. }\end{array}$ \\
\hline
\end{tabular}

(Sumber : Data hasil survei, 2017)

Kondisi Fasilitas penunjang halte 03

Tabel 13. Kondisi fasilitas penunjang halte 03

\begin{tabular}{|c|c|c|c|}
\hline No & Jenis Fasillitas & Kondisi & Keterangan \\
\hline 1. & Telephon umum & Belum ada & Belum terpasangpada halte \\
\hline 2. & Tempat sampah & Belum ada & Belum adapadahalte \\
\hline 3. & Pagar pengaman & Belum ada & Belum terpasangpada halte \\
\hline
\end{tabular}

(Sumber : Data hasil survei, 2017)

\section{Halte 04 dan halte 05}

Halte ini berada depan perumahan, halte ini masuk pada kelompok halte jenis ganda, Berikut ini hasil survai yang di lakukan pada halte.

Kondisi Fasilitas utama halte 04

Tabel 14. Kondisi fasilitas utama halte 04 


\begin{tabular}{|c|c|c|c|}
\hline No & Jenis Fasilitas & Kondisi & Keterangan \\
\hline 1 & Bangunan halte & Ada & $\begin{array}{l}\text { 1. Bangunan halte ini menggunakan } \\
\text { dinding setengah beton. } \\
\text { 2. jendela kaca yang masih utuh } \\
\text { 3. pintu masuk, pintu keluar halte, } \\
\text { dan pintu akses masuk bus hilang }\end{array}$ \\
\hline 2 & Identitas halte & Belum ada & Belum terpasangpada halte \\
\hline 3 & Rambu petunjuk & Belum ada & Belum terpasang pada area halte. \\
\hline 4 & $\begin{array}{l}\text { Papan informasi } \\
\text { trayek }\end{array}$ & Belum ada & Belum terpasang pada halte \\
\hline 6 & Tempat duduk & Ada & $\begin{array}{l}\text { 1. Tempat duduk terbuat dari pipa } \\
\text { besi, ukuran sandaran dan lebar } \\
\text { tempat duduk belum memenuhi } \\
\text { ukuran halte yang ergonomis. }\end{array}$ \\
\hline 7 & $\begin{array}{l}\text { Fasilitas } \\
\text { pengatur suhu } \\
\text { ruangan atau } \\
\text { ventilasi udara. }\end{array}$ & Belum ada & $\begin{array}{l}\text { 1. memiliki fentilasi dan masi } \\
\text { berfungsi. }\end{array}$ \\
\hline 8 & $\begin{array}{c}\text { Fasilitas } \\
\text { Penyebrangan }\end{array}$ & Belum ada & $\begin{array}{l}\text { Fasilitas Penyebrangan Zebra } \\
\text { Croos belum ada. }\end{array}$ \\
\hline
\end{tabular}

(Sumber : Data hasil survei, 2017)

Tabel kondisi fasilitas utama halte 04

Tabel 15. Kondisi fasilitas Penunjang halte 04.

\begin{tabular}{|c|c|c|c|}
\hline No & Jenis Fasillitas & Kondisi & Keterangan \\
\hline 1. & Telephon umum & Belum ada & Belum terpasangpada halte \\
\hline 2. & Tempat sampah & Belum ada & Belum adapada halte \\
\hline 3. & Pagar pengaman & Belum ada & Belum terpasang pada halte \\
\hline
\end{tabular}

(Sumber : Data hasil survei, 2017)

Kondisi Fasilitas utama halte 05

Tabel 16. Kondisi fasilitas utama halte 05

\begin{tabular}{|c|c|c|c|}
\hline No & Jenis Fasilitas & Kondisi & Keterangan \\
\hline 1 & Bangunanhalte & Ada & $\begin{array}{l}\text { 1. Kondisi atap halte yang bocor. } \\
\text { 2. Plafon yang rusak. } \\
\text { 3. Tangga akses masuk rusak. } \\
\text { 4. Tempat duduk yang sebagian } \\
\text { hilang. }\end{array}$ \\
\hline No & Jenis Fasilitas & Kondisi & Keterangan \\
\hline 2 & Identitas halte & Belum ada & Belum terpasangpadahalte \\
\hline 3 & Rambupetunjuk & Ada & 1. laranganparkirpada area halte. \\
\hline 4 & $\begin{array}{l}\text { Papaninformasi } \\
\text { trayek }\end{array}$ & Belum ada & Belum terpasang pa da halte \\
\hline 5 & $\begin{array}{c}\text { Lampu } \\
\text { penerangan }\end{array}$ & Belum ada & Belum terpasang pada halte \\
\hline 6 & Tempat duduk & Ada & $\begin{array}{l}\text { 1. Tempat duduk sebahagian hilang. } \\
\text { dan rusak. }\end{array}$ \\
\hline 7 & $\begin{array}{c}\text { Fasilitas } \\
\text { pengatur suhu } \\
\text { ruangan atau } \\
\text { ventilasi udara. }\end{array}$ & Belum ada & 2. Memiliki Fentilasi udara. \\
\hline 8 & $\begin{array}{c}\text { Fasilitas } \\
\text { Penyebrangan }\end{array}$ & Belum ada & $\begin{array}{l}\text { Fasilitas Penyebrangan Zebra } \\
\text { Croos Belum ada. }\end{array}$ \\
\hline
\end{tabular}

(Sumber : Data hasil survei, 2017)

Tabel 17. Kondisi fasilitas Penunjang halte 05.

\begin{tabular}{|l|l|l|l|}
\hline No & $\begin{array}{l}\text { Fasilitas } \\
\text { tambahan }\end{array}$ & Kondisi & Keterangan \\
\hline 1 & Telephon umum & Belum ada & Belum terpasang pada halte \\
\hline 2 & Tempat sampah & Belum ada & Belum adapada halte \\
\hline 3 & Pagarpengaman & Belum ada & Belum terpasang pada halte \\
\hline
\end{tabular}

(Sumber : Data hasil survei, 2017)

\section{Halte 06}

Halte ini berada tidak jauh dari depan pitu gerbang masuk jalan pandau permai, halte ini masuk pada kelompk tempat henti (tunggal) dengan trotoar dan tidak dilengkapi dengan teluk bus. Berikut ini hasil survai yang di lakukan pada halte.

Tabel 18. Kondisi fasilitas utama halte 06

\begin{tabular}{|c|c|c|c|}
\hline No & Jenis Fasilitas & Kondisi & Keterangan \\
\hline 1 & Bangunan halte & Ada & $\begin{array}{l}\text { 1. Kondisi atap halte yang bocor. } \\
\text { 2. Plafon yang rusak. } \\
\text { 3. Tangga beton akses masuk rusak. } \\
\text { 4. Tempat duduk yang sebagian } \\
\text { hilang. } \\
\text { 5. Pintu masuk dan pintu menuju ke } \\
\text { bus sudah tidak ada. }\end{array}$ \\
\hline 2 & Identitas halte & Belum ada & Belum terpasang pada halte \\
\hline 3 & Rambu petunjuk & Ada & Belum terpasang pada halte \\
\hline 4 & $\begin{array}{l}\text { Papan informasi } \\
\text { trayek }\end{array}$ & Belum ada & Belum terpasang pada halte \\
\hline 5 & $\begin{array}{c}\text { Lampu } \\
\text { penerangan }\end{array}$ & Belum ada & Belum terpasang pada halte \\
\hline 6 & Tempat duduk & Ada & $\begin{array}{l}\text { 1. Tempat duduk sebahagian hilang, } \\
\text { dan rusak. }\end{array}$ \\
\hline 7 & $\begin{array}{c}\text { Fasilitas } \\
\text { pengatur suhu } \\
\text { ruangan atau } \\
\text { ventilasi udara. }\end{array}$ & Belum ada & $\begin{array}{l}\text { Memiliki jendela menggunakan } \\
\text { tralis besi, dan tampa fentilasi. }\end{array}$ \\
\hline 8 & $\begin{array}{c}\text { Fasilitas } \\
\text { Penyebrangan }\end{array}$ & Belum ada & $\begin{array}{l}\text { Fasilitas Penyebrangan } \\
\text { Croos Belum ada. }\end{array}$ \\
\hline
\end{tabular}

(Sumber : Data hasil survei, 2017)

Tabel 19. Kondisi fasilitas Penunjang halte 06.

\begin{tabular}{|l|l|c|c|}
\hline No & Jenis Fasilitas & Kondisi & Keterangan \\
\hline 1 & Telephon umum & Belum ada & Belum terpasang pada halte \\
\hline 2 & Tempat sampah & Belum ada & Belum ada pada halte \\
\hline 3 & Pagar pengaman & Belum ada & Belum terpasang pada halte \\
\hline
\end{tabular}

(Sumber : Data hasil survei, 2017)

\section{Halte 07 dan Halte 08}

Halte ini berada pada perumahan halte ini masuk pada kelompk jenis halte ganda dan dilengkapi dengan trotoal, dan tidak dilengkapi dengan teluk bus. Berikut ini hasil survai yang di lakukan pada halte.

Tabel 20. Kondisi fasilitas utama halte 07 


\begin{tabular}{|c|c|c|c|}
\hline No & Jenis Fasilitas & Kondisi & \multicolumn{1}{|c|}{ Keterangan } \\
\hline 1 & Bangunan halte & Ada & $\begin{array}{l}\text { 1. Kondisi atap halte yang bocor. } \\
\text { 2. Plafon yang rusak. } \\
\text { 3. Tidak ada teralis besi. } \\
\text { 4. Dinding halte sebelah kanan } \\
\text { sudah tidak ada. } \\
\text { 5. Pintu masuk dan pintu menuju ke } \\
\text { bus sudah tidak ada. }\end{array}$ \\
\hline 2 & Identitas halte & Belum ada & Belum terpasang pada halte \\
\hline 3 & Rambu petunjuk & Ada & Belum terpasang pada area halte \\
\hline 4 & $\begin{array}{c}\text { Papan informasi } \\
\text { trayek }\end{array}$ & Belum ada & Belum terpasang pada halte \\
\hline 5 & $\begin{array}{c}\text { Lampu } \\
\text { penerangan }\end{array}$ & Belum ada & Belum terpasang pada halte \\
\hline 6 & $\begin{array}{c}\text { Tempat duduk } \\
\text { pengatur suhu } \\
\text { ruangan atau } \\
\text { ventilasi udara. }\end{array}$ & Belum ada & Belum terpasang pada halte \\
\hline 8 & $\begin{array}{c}\text { Fasilitas } \\
\text { Penyebrangan }\end{array}$ & Belum ada & $\begin{array}{l}\text { Fasilitas Pendela tidak ada penutup, } \\
\text { Croos Belum ada. }\end{array}$ \\
\hline
\end{tabular}

(Sumber : Data hasil survei, 2017)

Tabel kondisi fasilitas Penunjang halte 07

Tabel 21. Kondisi fasilitas Penunjang halte 07.

\begin{tabular}{|l|l|l|l|}
\hline No & Jenis Fasilitas & Kondisi & Keterangan \\
\hline 1 & Telephon umum & Belum ada & Belum terpasang pada halte \\
\hline 2 & Tempat sampah & Belum ada & Belum ada pada halte \\
\hline 3 & Pagar pengaman & Belum ada & Belum terpasang pada halte \\
\hline
\end{tabular}

(Sumber : Data hasil survei, 2017)

Tabel 22. Kondisi fasilitas utama halte 08

\begin{tabular}{|c|c|c|c|}
\hline No & Jenis Fxilitas & Kondisi & Keler angan \\
\hline 1 & Bunguma halte & Ads & $\begin{array}{l}\text { 1. Koodissi gap baik } \\
\text { 2 Plafon rusak. } \\
\text { 3. Tidak adh dinding } \\
\text { 1. Halte tinggal tiang besi . } \\
\text { 5. Lantai Tidak dapat digumakan } \\
\text { lagi. }\end{array}$ \\
\hline 2 & Identitas balite & Belum aAs & Belum terpasang pada lasite \\
\hline 3 & Rambu petuajuk & Ada & $\begin{array}{l}\text { Helam terpasang pada area } \\
\text { halno }\end{array}$ \\
\hline 4 & $\begin{array}{c}\text { Papan informasi } \\
\text { trayek }\end{array}$ & Belum ada & Belum terpasang pada balte \\
\hline s & $\begin{array}{c}\text { Larryu } \\
\text { penerangan }\end{array}$ & Belum ada & Belum terpasang pada balte \\
\hline 0 & Temput duduk & Belum ada & Tidalk ada dalam balte \\
\hline 7 & $\begin{array}{l}\text { Frsilitas } \\
\text { pengatur subu } \\
\text { ruangan atmu } \\
\text { ventilasi udara. }\end{array}$ & Belum ada & 1. Jendela tidak ada peratup kaca \\
\hline 8 & $\begin{array}{c}\text { Fesilitas } \\
\text { Perveltranzan }\end{array}$ & Belum aca & $\begin{array}{l}\text { Fasilitas Peayebrangath Zebra } \\
\text { Croos Belum ada. }\end{array}$ \\
\hline
\end{tabular}

(Sumber : Data hasil survei, 2017)

Tabel kondisi fasilitas Penunjang halte 08

Tabel 23. Kondisi fasilitas Penunjang halte 08.

\begin{tabular}{|l|l|c|c|}
\hline No & Jenis Fasilitas & Kondisi & Keterangan \\
\hline 1 & Telephon umum & Belum ada & Belum terpasang pada halte \\
\hline 2 & Tempat sampah & Belum ada & Belum ada pada halte \\
\hline 3 & Pagar pengaman & Belum ada & Belum terpasang pada halte \\
\hline
\end{tabular}

(Sumber : Data hasil survei, 2017)

\section{Halte 09}

Halte ini berada pada perumahan halte ini masuk pada kelompk jenis halte tunggal, dilengkapi dengan trotoal, dan tidak dilengkapi dengan teluk bus. Berikut ini hasil survai yang di lakukan pada halte.

Kondisi fasilitas utama halte 09

Tabel 24. Kondisi fasilitas utama halte 09

\begin{tabular}{|c|c|c|c|}
\hline No & Jenis Fasilitas & Kondisi & Keterangan \\
\hline 1 & Bangunan halte & Ada & $\begin{array}{l}\text { 1. Struktir atap kanopi. } \\
\text { 2. Tidak mempunyai plafon. } \\
\text { 3. Tidak memiliki dinding samping } \\
\text { dan depan. }\end{array}$ \\
\hline 2 & Identitas halte & Belum ada & 1. terpasang pada bagian atas halte \\
\hline 3 & Rambu petunjuk & Ada & Belum terpasang pada area halte \\
\hline 4 & $\begin{array}{c}\text { Papan informasi } \\
\text { trayek }\end{array}$ & Belum ada & Belum terpasang pada halte \\
\hline 5 & $\begin{array}{c}\text { Lampu } \\
\text { penerangan }\end{array}$ & Belum ada & Belum terpasang pada halte \\
\hline 6 & Tempat duduk & Belum ada & 1. bangku terbuat dari pipa besi \\
\hline 7 & $\begin{array}{c}\text { Fasilitas } \\
\text { pengatur suhu } \\
\text { ruangan atau } \\
\text { ventilasi udara. }\end{array}$ & Belum ada & Belum terpasang pada halte \\
\hline 8 & $\begin{array}{c}\text { Fasilitas } \\
\text { Penyebrangan }\end{array}$ & Belum ada & Belum ada pada halte \\
\hline
\end{tabular}

(Sumber : Data hasil survei, 2017)

Tabel kondisi fasilitas Penunjang halte 09

Tabel 25. Kondisi fasilitas Penunjang halte 09.

\begin{tabular}{|l|l|c|c|}
\hline No & Jenis Fasilitas & Kondisi & Keterangan \\
\hline 1 & Telephon umum & Belum ada & Belum terpasang pada halte \\
\hline 2 & Tempat sampah & Belum ada & Belum ada pada halte \\
\hline 3 & Pagar pengaman & Belum ada & Belum terpasang pada halte \\
\hline
\end{tabular}

(Sumber : Data hasil survei, 2017)

\section{Halte 10}

Halte ini berada pada perumahan dan pasar halte ini masuk pada kelompk jenis halte tunggal, dilengkapi dengan trotoal, dan tidak dilengkapi dengan teluk bus. Berikut ini hasil survai yang di lakukan pada halte.

Kondisi fasilitas utama halte 10

Tabel 26. Kondisi fasilitas utama halte 10 


\begin{tabular}{|c|c|c|c|}
\hline No & Jenis Fasilitas & Kondisi & Keterangan \\
\hline 1 & Bangunan halte & Ada & $\begin{array}{l}\text { 1. Kondisi atap baik. } \\
\text { 2. Plafon rusak. } \\
\text { 3. Tidak ada dinding. } \\
\text { 4. Halte tinggal tiang besi } \\
\text { 5. Lantai Tidak dapat digunakan lagi. }\end{array}$ \\
\hline 2 & Identitas halte & Belum ada & Belum terpasang pada halte \\
\hline 3 & $\begin{array}{l}\text { Rambu } \\
\text { petunjuk }\end{array}$ & Ada & Belum terpasang pada area halte \\
\hline 4 & $\begin{array}{c}\text { Papan } \\
\text { informasi } \\
\text { trayek }\end{array}$ & Belum ada & Belum terpasang pada halte \\
\hline 5 & $\begin{array}{c}\text { Lampu } \\
\text { penerangan }\end{array}$ & Belum ada & Belum terpasang pada halte \\
\hline 6 & Tempat duduk & Belum ada & Tidak ada dalam halte \\
\hline 7 & $\begin{array}{c}\text { Fasilitas } \\
\text { pengatur suhu } \\
\text { ruangan atau } \\
\text { ventilasi udara. }\end{array}$ & Belum ada & Belum terpasang pada halte \\
\hline 8 & $\begin{array}{c}\text { Fasilitas } \\
\text { Penyebrangan }\end{array}$ & Belum ada & $\begin{array}{lll}\text { Fasilitas Penyebrangan } & \text { Zebra } \\
\text { Croos Belum ada. } & \\
\end{array}$ \\
\hline
\end{tabular}

(Sumber : Data hasil survei, 2017)

Tabel kondisi fasilitas Penunjang halte 10

Tabel 27. Kondisi fasilitas Penunjang halte 10.

\begin{tabular}{|l|l|c|c|}
\hline No & Jenis Fasilitas & Kondisi & Keterangan \\
\hline 1 & Telephon umum & Belum ada & Belum terpasang pada halte \\
\hline 2 & Tempat sampah & Belum ada & Belum ada pada halte \\
\hline 3 & Pagar pengaman & Belum ada & Belum terpasang pada halte \\
\hline
\end{tabular}

(Sumber : Data hasil survei, 2017)

\section{Halte 11}

Halte ini berada pada perumahan halte ini masuk pada kelompk jenis halte tunggal, dilengkapi dengan trotoal, dan tidak dilengkapi dengan teluk bus. Berikut ini hasil survai yang di lakukan pada halte.

Kondisi fasilitas utama halte 11

Tabel 28. Kondisi fasilitas utama halte 11

\begin{tabular}{|c|c|c|c|}
\hline No & Jenis Fasilitas & Kondisi & Keterangan \\
\hline 1 & Bangunan halte & Ada & $\begin{array}{l}\text { 1. Kondisi atap baik. } \\
\text { 2. Plafon rusak. } \\
\text { 3. Tidak ada jendela kaca } \\
\text { 4. Halte tinggal tiang besi }\end{array}$ \\
\hline 2 & Identitas halte & Belum ada & Belum terpasang pada halte \\
\hline 3 & Rambu petunjuk & Ada & Belum terpasang pada area halte \\
\hline 4 & $\begin{array}{l}\text { Papan informasi } \\
\text { trayek }\end{array}$ & Ada & 1. Jadwal keberangkatan ada \\
\hline 5 & $\begin{array}{c}\text { Lampu } \\
\text { penerangan }\end{array}$ & Belum ada & Belum terpasang pada halte \\
\hline 6 & Tempat duduk & Ada & 1. bangku terbuat dari beton \\
\hline 7 & $\begin{array}{c}\text { Fasilitas } \\
\text { pengatur suhu } \\
\text { ruangan atau } \\
\text { ventilasi udara. }\end{array}$ & Belum ada & Belum terpasang pada halte \\
\hline No & Jenis Fasilitas & Kondisi & Keterangan \\
\hline 8 & $\begin{array}{c}\text { Fasilitas } \\
\text { Penyebrangan }\end{array}$ & Belum ada & $\begin{array}{l}\text { Fasilitas Penyebrangan } \\
\text { Croos Belum ada. }\end{array}$ \\
\hline
\end{tabular}

(Sumber : Data hasil survei, 2017)
Halte yang berada pada jalan Pasir Putih dan Pandau Permai ini yang memiliki teluk adalah halte 01dan hale 02 yang dengan tipe Perhentian ganda atau saling berseberangan. Pemberhenian halte dengan tipe lay-bys, menggunakan teluk dapat kita lihat pada gambar 12. sebagai berikut.

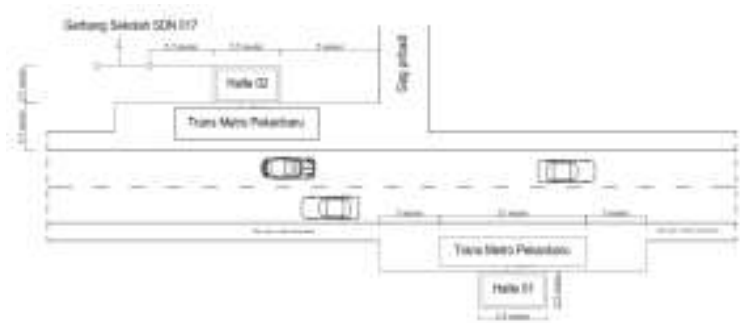

Gambar 12. Situasi teluk halte pada halte 01 dan halte 02

(Sumber : Data hasil survei, 2017)

\section{PEMBAHASAN}

Pada pembahasan penelitian ini yang akan di analisis adalah jarak halte, tipe pemberhentian, jenis banguanan, kondisi fasilitas halte dan kondisi teluk halte. Penilitian ini berdasarkan Peraturan yang ada.

\section{Jarak halte}

Jarak antara halte yang telah di atur dalam Peramen Perhubungan No.10.2012 yang di mana disana sudah di jelaskan jarak halte yang di anjurkan adalah dari 300-400 meter daerah dalam kota, dan 500-1000 meter di luar kota. Dalam pembangunan beberapa halte di jalan Pasir Putih dan Pandau Permai memiliki jarak yang jauh, sehingga membuat calon penumpang transmetro Pekanbaru harus menempuh jarak yang jauh untuk menuju halte.

\section{Tipe pemberhentian bus pada halte}

Banyaknya penggunaan halte dengan tipe curbside perlu memperhatikan kondisi lalu lintas yang ada pada lokasi dimana perhentian terletak, sehingga saat pemilihan tipe pemberhentian halte tidak menggangu lalulintas lainnya.

\section{Jenis bangunan halte}

Kejadian penyempitan ruas jalan tersebut kerap terjadi pada halte ganda dan hate tunggal yang tidak memiliki teluk sehingga dapat menyebabkan gangguan pada lalulintas lainya.

\section{Kondisi Fasilitas Halte}

Agar terciptanya halte yang nyaman dan baik perlu memperhatikan fasilitas-fasilitas berdasarkan kebutuhan pada halte baik fasilitas umum dan fasilitas penunjang. Analisis berdasararkan kelengkapan halte masing-masing fasilitas diberikan bobot nilai yang sama, dengan nilai sebagai bserikut

$$
\frac{\text { masing }- \text { masing fasilitas }}{\text { Jumlah fasilitas }} \times 100 \%
$$

\section{Kondisi Teluk bus}




$$
\frac{1}{11} \times 100 \%=9,09 \%
$$

Maka dari hasil perhitungan di atas di dapat setaip masing-masing fasilitas memiliki nilai bobot persentase yang sama, dengan rentamg nilai penilaian persentase kelengkapan halte di masing-masing halte yang sudah terpenuhi, berdasarkan fasilitas umum dan fasilitas penunjang pada halte dapat kita liat pada table 30 . Persentase penilaian kelengkapan fasilitas halte berdasarkan No 271/HK.105/DRJD/96, antara lain sebagai berikut.

Tabel 30. Persentase penilaian kelengkapan fasilitas halte berdasarkan No271/HK.105/DRJD/96.

\begin{tabular}{|c|c|}
\hline Persentase Kelengkapan & Keterangan \\
\hline $80,00-100$ & Sangat Lengkap \\
\hline $50,00-77,99$ & Lengkap \\
\hline $00.00-49,99$ & Kurang Lengkap \\
\hline
\end{tabular}

(Sumber : Data hasil survei, 2017)

Analisi yang telah di lakukan terhadap halte Pasir Putih dan Pandau Permai, untuk nilai kelengkapan masing masing halte dibuat dalam bentuk tabel rekapitulasi fasilitas pada halte sebagai berikut.

Dari hasil analisis yang di lakukan terhadap 11 halte yang berada pada jalan Pasir Putih dan Pandau Permai, fasilitas-fasilitas yang ada pada halte terdiri dari 8 fasilitas utama dan 3 fasilitas penunjang, yang telah di atur oleh Permen Perhubungan No 271/HK.105/DRJD/96, belum sepenuhnya terpenuhi.

Nilai persentasi tertinggi mencapai 36,36\% fasilitas yang sudah ada dan nilai terendah 9,09 \% fasilitas yang sudah ada. Maka dari tabel 30. Persentase penilaian pada fasilits halte, berada pada penilaian kurang lengkap.

\section{Kondisi teluk bus}

Dari 11 halte dan tiga jenis halte pemberhentian ganda atau saling berseberangan, halte yang menggunakan teluk terdapat pada halte 01dan hale 02 yang menggunakan tipe lay-bys.

Kondisi teluk halte pada halte 02 yang di bangun di depan SDN 017 ini sangat dekat dengan persimpangan jalan baik itu Jalan masuk gerbang sekolah maupun jalan masuk gag pribadi. Dengan ukuran kendaraan bus Trans Metro Pekanbaru berdampak pada pengguna jalan lainnya.

Dalam pembuatan teluk harus memperhatikan tata letak halte berdasakan Perhubungan No 271/HK.105/DRJD/96, yang menjelaskan jarak minimal halte dari persimpangan adalah 50 meter.

\section{KESIMPULAN DAN SARAN}

\section{Kesimpulan}

Berdasarkan hasil analisis kelengkapan utilitas halte jalan Pasir Putih dan Pandau Permai yang telah dilakukan, maka diperoleh kesimpulan bahwa kondisi halte transmetro Pekanbaru dari 8 fasilitas utama dan 3 fasilitas penunjang, yang telah di atur oleh Permen
Perhubungan No 271/HK.105/DRJD/96. Hasil nilai persentasi tertinggi mencapai $36,36 \%$ dan nilai terendah 9,09\% fasilitas yang sudah ada. Maka dari tabel Persentase penilaian fasilits halte masih berada pada penilaian kurang lengkap, kondisi fasilitas-fasilitas yang ada dalam pembangunan halte tersebut belum memenuhi kelengkapan berdasarkan pedoman teknis perekayasaan tempat pemberhentian kendaraan penumpang umum yang di atur oleh permen perhubungan direktur jendral perhubungan darat.

\section{Saran}

Berdasarkan kesimpulan dari evaluasi kelengkapan utilitas halte Trans Metro Pekanbaru penulis memberikan saran sebagai berikut :

1. Dinas terkait seharusnya melakukan evaluasi perbaikan terhadap fasilitas-fasilitas halte yang telah di bangun sehingga dapat di gunakan dengan baik oleh masyarakat.

2. Pembangunan kebutuhan angkutan umum perlu memperhatian dalam aspek aksesibilitas halte, sehinngga dapat di gunakan pada kaum difabel.

3. Perencanaan pembangunan halte harus memperhatikan kebutuhan halte sesuai dengan pedoman teknis perekayaasaan tempat pemberhentian kendaraan penumpang umum.

\section{DAFTAR PUSTAKA}

Gde Agung Asmara A.A. 2016. Evaluasi Kinerja Halte Bus Dalam Upaya Meningkatkan Pelayanan Bus Trans Sarbagita, Denpasar. Jurnal teknik Sipil.

Keputusan Direktorat Jenderal Bina Marga No. 038/TBM/1997 Tata Cara Perencanaan Geometrik Jalan Antar Kota. Jakarta : Direktorat Jenderal Bina Marga

Keputusan Undang-undang Peraturan Pemerintah Republik Indonesia. Tentang Angkutan jalan No 41 Tahun 1997. Jakarta : Menteri Perhubungan darat

Keputusan Direktorat Jendral Perhubungan Darat No: sk.271/HK.105/DRJD/96, Pedoman Teknis Perekayasanaan Tempat Perhentian Kendaraan penumpang uтиm. Jakarta : Menteri Perhubungan darat

Keputusan Direktur Jenderal Perhubungan Darat No: sk.687/aj.206/drjd/2002 Pedoman Teknis Penyelenggaraan Angkutan Penumpang Umum Di Wilayah Perkotaan Dalam Trayek Tetap Dan Teratur. Jakarta : Menteri Perhubungan darat 